\title{
A Wandering Intravascular Scalpel Fragment After Lumbar Discectomy: A Case Report
}

\author{
Lomber Diskektomi Sonrası Damar Içinde Dolaşan Bistüri Parçası: \\ Olgu Sunumu
}

Adem Bozkurt ARAS ${ }^{1}$, Omer Faruk OZKAN ${ }^{2}$, Timucin $\mathrm{ALAR}^{3}$, Adile OZKAN ${ }^{4}, \mathrm{M}$. Kasım ARIK ${ }^{2}$, Sule KOSAR Bahadır KIRILMAZ ${ }^{6}$, Betul KIZILDAG ${ }^{5}$, Tarık AKMAN ${ }^{1}$, Tolga KURT ${ }^{7}$, Bahadır ALKAN ${ }^{1}$, Mustafa SACAR ${ }^{7}$, Murat COSAR ${ }^{1}$

${ }^{1}$ Canakkale 18 March University, School of Medicine, Department of Neurosurgery, Canakkale, Turkey ${ }^{2}$ Canakkale 18 March University, School of Medicine, Department of General Surgery, Canakkale, Turkey

${ }^{3}$ Canakkale 18 March University, School of Medicine, Department of Thoracic Surgery, Canakkale, Turkey

${ }^{4}$ Canakkale 18 March University, School of Medicine, Department of Neurology, Canakkale, Turkey

${ }^{5}$ Canakkale 18 March University, School of Medicine, Department of Radiology, Canakkale, Turkey

${ }^{6}$ Canakkale 18 March University, School of Medicine, Department of Cardiology, Canakkale, Turkey

${ }^{7}$ Canakkale 18 March University, School of Medicine, Department of Cardiothoracic Surgery, Canakkale, Turkey

Corresponding Author: Adem Bozkurt ARAS / E-mail: adem_aras@yahoo.com

\begin{abstract}
Vascular complications after lumbar discectomy are rarely seen. We present a unique and potentially life-threatening postoperative complication from this procedure. A 27-year-old man was admitted to our emergency vascular unit 1 day after a lumbar discectomy, during which a scalpel blade fragmented and a part was lost. Radiological images of the patient were performed and a broken scalpel blade was located anterior to the sacrum. An anterior laparotomy was performed which identified a mass within the left iliac vein that migrated suddenly to the inferior vena cava. An emergency angiography was performed, by which time the scalpel blade had ascended to the right-sided inferior pulmonary artery. It was subsequently removed via a right lateral thoracotomy.
\end{abstract}

KEYWORDS: Iliac vein, Lumbar discectomy, Pulmonary artery, Scalpel

öz

Lomber diskektomi sonrası vasküler komplikasyonlar nadir görülür. Bu işlemden kaynaklanan nadir ve potansiyel olarak hayatı tehdit edici bir postoperatif komplikasyonu sunuyoruz. Yirmi yedi yaşındaki erkek hasta, lomber diskektomi işleminden 1 gün sonra, acil vasküler ünitesine başvurdu. Lomber diskektomi işlemi sonrasında bistüri parçası kırılmış ve sonrasında kaybolmuş. Hastada radyolojik incelemeler yapıldı ve kırılmış bistüri sapının sakrumun anteriorunda olduğu belirlendi. Anterior laparatomi yapıldı. Operasyon esnasında sol iliak ven içinden aniden inferior vena kavaya doğru ilerleyen kitle saptandı. Acil anjiyografi yapıldı. İşlem esnasında bistüri sapı sağ inferior pulmoner artere doğru ilerledi. Daha sonra lateral torakotomi yapılarak parçalanmış bistüri sapı çıkartıldı.

ANAHTAR SÖZCÜKLER: Illiak ven, Lomber diskektomi, Pulmoner arter, Bistüri

\section{INTRODUCTION}

Millions of spinal surgical approaches are performed routinely across the world each year. The vascular complication rate after lumbar discectomy is approximately 1-5/10,000, which is rare compared to after vascular surgery $(6,4)$. Major vascular injuries require prompt diagnosis and emergency treatment because of a reported mortality rate of more than $40 \%(4,7)$. The mortality rate is associated with the extent of the injury, time to diagnosis and the vessel diameter (7). This type of complication has been well documented in the literature after vascular surgery, but to date there has been no published reports of a wandering broken scalpel blade within the major blood vessels after spinal surgery.
Here, we report a case that presented with an intravascular mass after spinal surgery, which was due to a broken scalpel blade that migrated into the internal iliac vein and subsequently travelled to a pulmonary artery. We report the management of this unique condition and the treatment procedures that led to a successful outcome.

\section{CASE REPORT}

A 27-year-old man was admitted to our emergency unit after a lumbar L5-S1 level microdiscectomy operation, during which a scalpel blade had been broken and lost. The broken blade was lost at the L5-S1 level during extensive surgical manipulations including a total laminectomy. The scalpel fragment passed to the anterior part of the L5-S1 disc level 
and crossed the anterior longitudinal ligament, after which it was lost to direct vision.

The hemodynamic findings and other vital signs of the patient were normal. Radiological examinations, including radiography and a lumbar computed tomography (CT) scan were performed. The scalpel fragment measuring $12 \times 5 \mathrm{~mm}$ in diameter was found to be located at the anterior of the sacrum extending towards the left common iliac vein (Figure 1).

An explorative abdominal laparotomy was performed and the rectum was mobilized to visualize the anatomical landmarks. The sacrum was exposed and the bifurcation of the common iliac vein was identified proximally. Although this extensive exploration was aided by a peri-operative biplanar scope, we could not visualize the scalpel fragment, but a small injury was noted on the posterior aspect of the left common iliac vein (Figure 2A, B).

We decided to perform a peri-operative ultrasonography (USG) of the vascular structures, and this technique identified the scalpel fragment coated with a thick thrombus within the left common iliac vein. During this procedure, the fragment moved suddenly, disappearing upwards into the inferior vena cava (Figure $2 \mathrm{C}$ ). Surgery was concluded and an angiography was performed that showed the fragment had migrated into the right-sided pulmonary artery via the right atrium, right ventricle and pulmonary artery (Figure 2D). A contrast thoracic CT scan was performed that confirmed the location of the scalpel fragment was within the right inferior pulmonary artery (Figure 3). A right lateral thoracotomy was performed and the fragment was successfully extracted (Figure 4).

The patient was stabilized in the intensive care unit for 1 day, and discharged from hospital five days day after the thoracotomy. The patient had no long-term ill effects of this complication over the three months follow-up period.

\section{DISCUSSION}

Linton and White defined the major potential vascular injuries that could occur during spinal surgery (7). The rate of great vessel injury was reported to be rare at between 1 and 5 in 10,000 cases. However, the mortality rate stands at $40-$ $80 \%$ according to the injury and the importance of vessels involved (5). The location of vascular injury is related to the level of spinal surgery. Although injuries to the iliac artery and veins are seen during spinal surgery at the L4-S1 vertebral level, aortic and vena caval injuries can occur during spinal surgeries at the L1-3 vertebral level $(1,7)$.

Vascular injuries during spinal surgery can be divided into early and late categories. Lacerations to vessels are early vascular complications while arteriovenous fistulas and pseudoaneurysms are defined as late vascular complications (5). The present early complication developed after part of a broken scalpel blade was lost during posterior microdiscectomy. A literature search using PubMed and related online databases showed that our case is unique in its clinical presentation. We believe that the aggressive manipulations of the spinal surgeon and the sharpness of the scalpel led to the anterior movement of the fragment. In 1953, Leavens and Bradford reported that the defects in the anterior annulus fibrosus and longitudinal ligaments could allow great vessel injuries during spinal surgery $(3,5)$, which could have contributed to the complication in this case.

Hemodynamic signs during spinal surgery must be taken seriously. The rapid development of hypotension and tachycardia suggest great vessel injury, which carry a high mortality rate $(2,3)$. If this occurs, spinal surgery must be stopped and an emergency laparotomy with vascular interventions as required must be conducted.

Diagnostic angiography is gold standard technique for the investigation of cases that are hemodynamically stable after vascular injury (3). A lumbar CT was performed in this case to localize the scalpel fragment as the patient was stable (4),
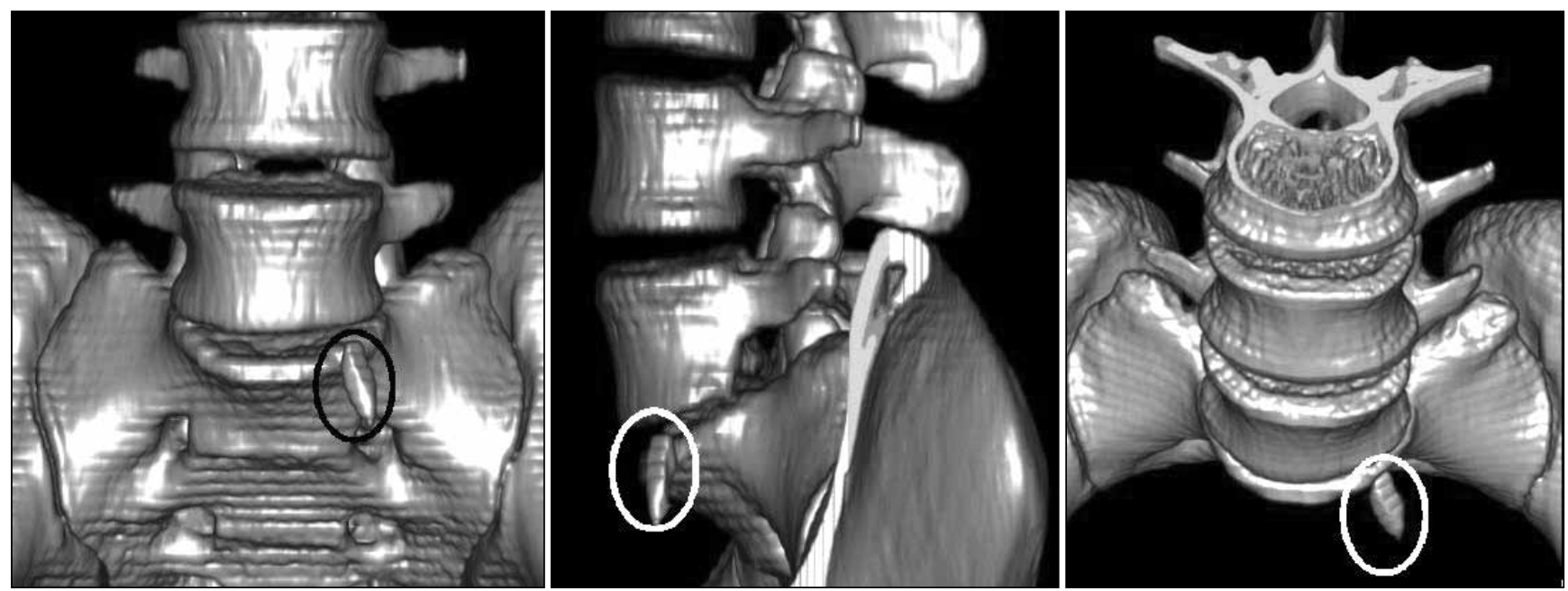

Figure 1: The 3D CT scan is showing the fragmented scalpel at the anterior location of L5-S1 disc level. 


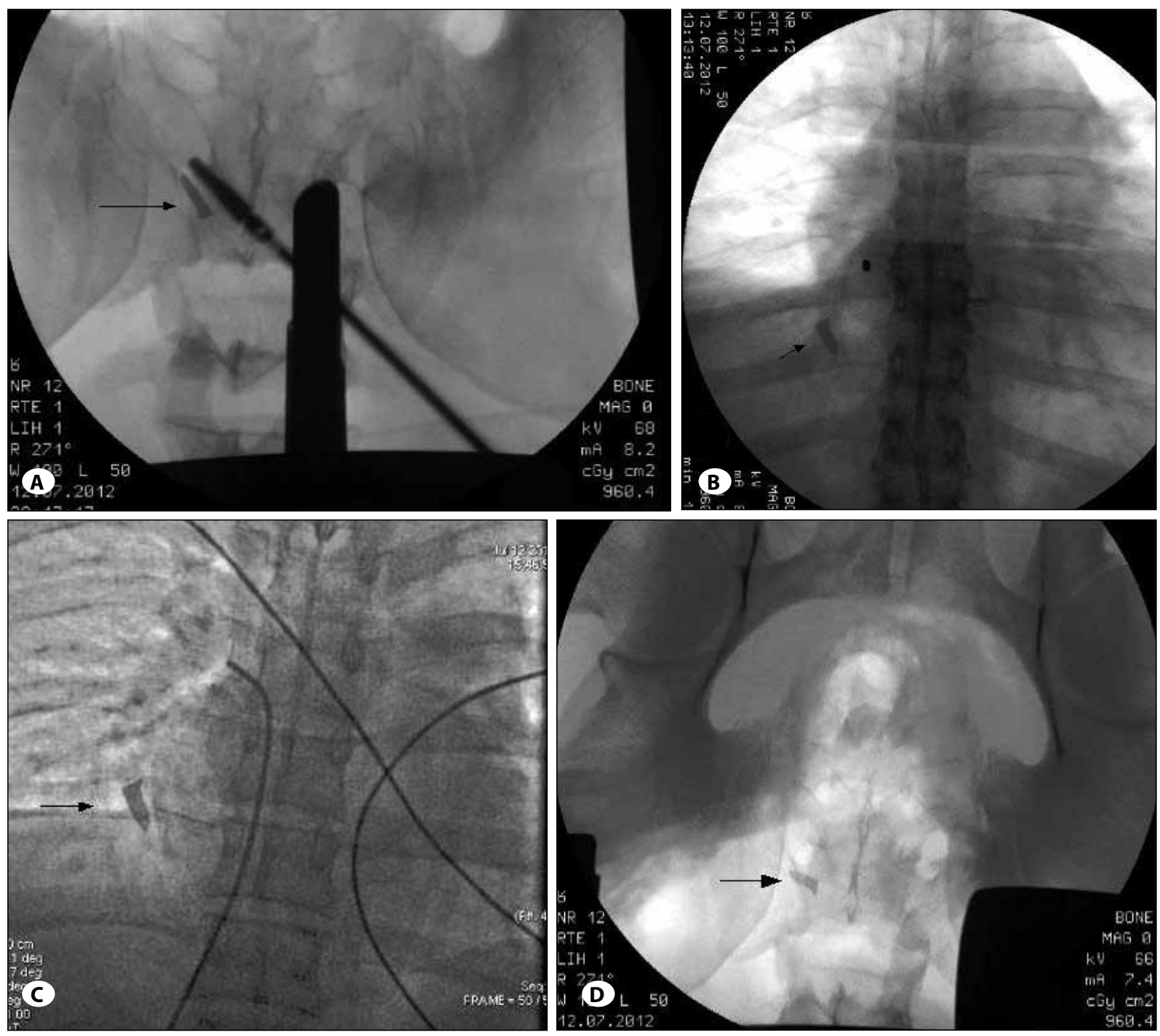

Figure 2: A, B) The peroperative biplanar scopy images showing the scalpel fragment at the anterior of the vertebral body. C) The peroperative scopy images showing the scalpel fragment in the inferior vena cava. D) The angiography images.

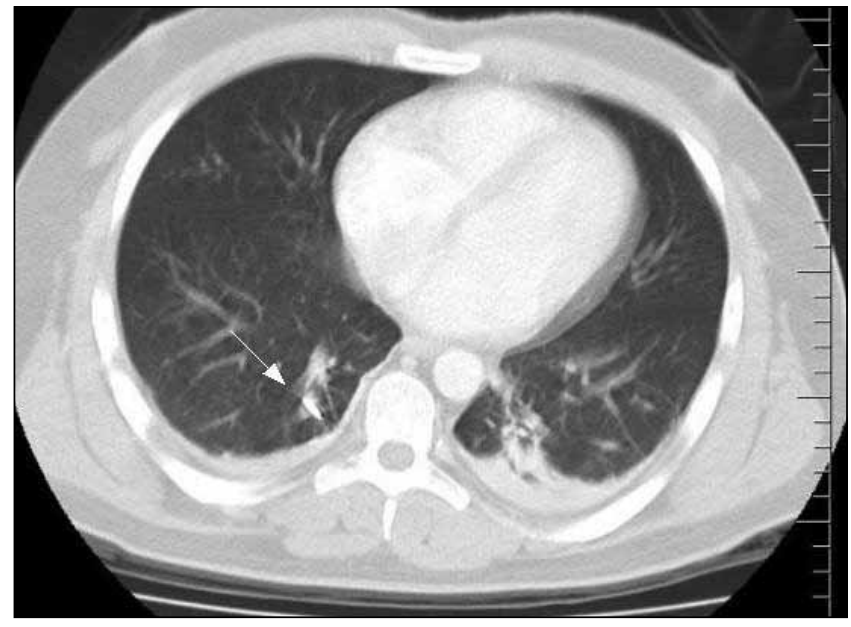

Figure 3:

The contrast enhanced thorax CT showing the scalpel fragment inside the right inferior pulmonary artery.

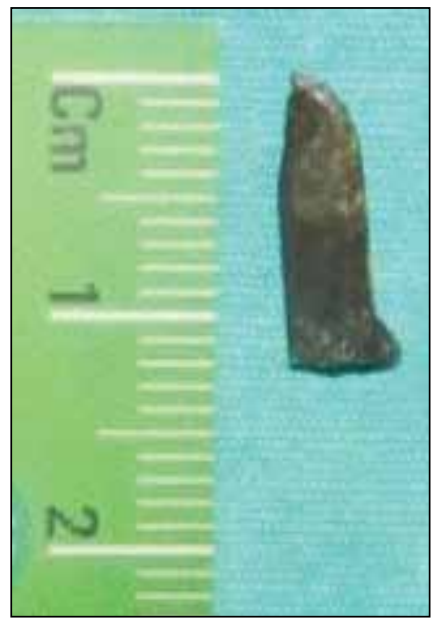

Figure 4:

The macroscopic view of the extracted scalpel fragment. 
and was indeed useful in the planning of the surgical strategy.

Our complicated case was managed with a multidisciplinary team, that included therapeutic angiography performed by cardiologists and neurosurgeons and cardiovascular surgeons who ultimately extracted the fragment from the pulmonary artery. This team undoubtedly avoided the death of this patient.

\section{CONCLUSION}

We conclude that the sharp surgical tools during spinal surgery must be used carefully and aggressive manipulations must not be used to retrieve lost surgical equipment. Spinal surgeons should be aware of the adjacent vascular and neural structures. In the event of such a complication, we recommend the involvement of a multidisciplinary team.

\section{REFERENCES}

1. Gallerani M, Maida G, Boari B, Galeotti R, Rocca T, Gasbarro V: High output heart failure due to an iatrogenic arteriovenous fistula after lumbar disc surgery. Acta Neurochir (Wien) 149: 1243-1247, 2007
2. Goodkin R, Laska LL: Vascular and visceral injuries associated with lumbar disc surgery: Medicolegal implications. Surgical Neurology 49 (4): 358-370; Discussion 370-372, 1998

3. Inamasu J, Guiot BH: Vascular injury and complication in neurosurgical spine surgery. Acta Neurochir (Wien) 148(4): 375-387, 2006

4. Libicher M, Bangard C, Gossmann A, Brukwall J, Gawenda $M$. Retroperitoneal hemorrhage after lumbar disc surgery: Importance of follow-up CT for detection of vascular complications. European Journal of Radiology Extra 67:95-97, 2008

5. Prabhakar H, Bithal PK, Dash M, Chaturvedi A: Rupture of aorta and inferior vena cava during lumbar disc surgery. Acta Neurochir (Wien) 147: 327-329, 2005

6. Pugely AJ, Martin CT, Gao Y, Mendoza-Lattes SA: Outpatient surgery reduces short-term complications in lumbar discectomy: An analysis of 4,310 patients from the ACS-NSQIP Database. Spine 38(3): 264-271,2013

7. Skippage P, Raja J, McFarland R, Belli AM: Endovascular repair of iliac artery injury complicating lumbar disc surgery. Eur Spine Journal 17 (2): 228-231, 2008 